\title{
PENGARUH KONDISI DEFISIENSI VITAMIN PADA MASA PANDEMI COVID- 19 TERHADAP RESIKO TERJADINYA PENYAKIT GUILLAIN BARRE SYNDROME :STUDI LITERATUR
}

\author{
Hariz Ghulam Ramadhan ${ }^{1}$ \\ ${ }^{1}$ Program Studi Pendidikan Dokter, Fakultas Kedokteran, Universitas Lampung
}

\begin{abstract}
Effect of Vitamin Deficiency Conditions in the Covid-19 Pandemic against the Risk of Guillain Barre Syndrome. Corona virus or SARS CoV-2 was first identified in December 2019 in Wuhan, Republic of China. Since its emergence, various scholarship on the relationship between Covid-19 and various bodily systems have emerged, one of which is related to the respiratory system. However, research on this virus continues and involves impacts on the nervous system. One of the rare symptoms that arise is a seizure, stroke, and cases of Guillain Barre Syndrome.Guillain Barre Syndrome is a demyelinating disease that is mediated by an immune response, acute or subacute in tone and is usually characterized by progressive weakness of the extremities, limb paresthesias, and relative areflexia. During the Covid-19 pandemic, vitamin supplementation was highly recommended. Vitamins $B 1$ and D become immunonutrition in a pandemic. Vitamin B1 (thiamine) deficiency can increase the risk of peripheral neuropathywhile vitamin $D$ plays an important role in calcium homeostasis and, thus, provides important support for bone growth by helping to mineralize the collagen matrix. Vitamin $D$ acts as an immunomodulator, anti-inflammatory, and antioxidant.
\end{abstract}

Keywords: Covid-19, Guillain Barre Syndrome, immune response, vitamin B, vitamin D

\begin{abstract}
Abstrak : Pengaruh Kondisi Defisiensi Vitamin pada Masa Pandemi Covid19 terhadap Resiko Terjadinya Penyakit Guillain Barre Syndrome.Corona virus atau SARS CoV-2 pertama kali teridentifikasi pada Desember 2019 di Wuhan, Republik Tiongkok. Sejak kemunculan tersebut, berbagai keilmuan mengenai hubungan Covid-19 dengan berbagai sistem tubuh pun bermunculan, salah satunya terkait dengan sistem respirasi. Namun, penelitian mengenai virus ini terus berlanjut dan melibatkan dampak pada sistem saraf. Salah satu gejala langka yang timbul adalah kejang, stroke, dan kasus Guillain Barre Syndrome. Guillain Barre Syndrome adalah penyakit demielinasi yang dimediasi oleh respon imun, beronset akut atau subakut dan biasanya ditandai dengan kelemahan progresif dari ekstremitas, parestesia ekstremitas, dan arefleksia relatif. Pada saat pandemi Covid-19, suplementasi vitamin sangatlah dianjurkan. Vitamin B1 dan D menjadi imunonutrisi di kala pandemi. Defisiensi vitamin B1 (tiamin) dapat meningkatkan resiko terjadinya neuropati perifer sedangkan vitamin $D$ berperan penting dalam homeostasis kalsium dan, dengan demikian, memberikan dukungan penting pada pertumbuhan tulang dengan membantu mineralisasi matriks kolagen. Vitamin $D$ bertindak sebagai imunomodulator, antiinflamasi,dan antioksidan.
\end{abstract}

Kata Kunci : Covid-19, Guillain Barre Syndrome, respon imun, vitamin B,vitamin D

PENDAHULUAN

$\begin{array}{cr}\text { WHO sebagai } & \text { organisasi } \\ \text { kesehatan } & \text { internasional }\end{array}$ memberikan peringatan mengenai virus Covid-19 yang awalnya berasal dari
Kota Wuhan, Tiongkok namun kini telah menjadi pandemi. Di Wuhan, beberapa kasus pneumonia diduga berasal dari infeksi virus Covid-19. Genom dari Covid-19 menampilkan urutan yang 
serupa dengan SARS-CoV dan MERSCov. Metode transmisi paling banyak adalah melalui inhalasi dari aerosol infeksius. Periode inkubasi berlangsung 3-14 hari (Kannan et al., 2020). Gejala Covid-19 terbagi menjadi gejala spesifik dan non-spesifik. Gejala spesifik berupa pneumonia sedangkan gejala non-spesifik dapat berupa demam, batuk, mialgia, dispnea dengan atau tanpa diare. Penyakit ini memiliki progresivitas yang sangat tinggi sehingga bisa memicu hipoksemia (Kannan et al., 2020).

Infeksi Corona virus telah dikaitkan dengan manifestasi neurologis ,misalkan kejang demam,perubahan status mental, dan ensefalitis .Kemampuan neurotropik dan neuroinvasif dari Corona virus telah dijelaskan pada manusia. Setelah menginfeksi hidung, Corona virus mulai memasuki SSP melalui bulbus olfaktorius dan menyebabkan terjadinya proses inflamasi dan dapat mengakibatkan terjadinya demielinasi (Asadi-pooya, 2020).

Sebagian besar Corona virus memiliki struktur virus dan jalur infeksi yang serupa. Patomekanisme yang ditemukan juga berlaku untuk SARSCoV2. Virus korona pada manusia tidak selalu menyerang saluran pernapasan melainkan dapat menyerang CNS. Infeksi SARS-CoV telah banyak dikaitkan dengan manifestasi neurologis (Asadi-pooya, 2020).

Kelainan saraf yang dapat muncul adalah Guillain-BarrèSyndrome. Penyakit ini terjadi akibat infeksi virus yang bersifat langka dan merupakan penyebab paling sering dari kelemahan simetris akut pada tungkai dan arefleksia biasanya mencapai puncaknya dalam waktu sebulan. Pada tahun 1949 , Haymaker dan rekannya menggambarkan fitur klinis dari 50 kasus GBS fatal dan mencatat adanya degenerasi aksonal, kerusakan mielin, dan edema saraf. Pada tahun 1986, Feasby dan rekannya lebih lanjut menggambarkan varian GBS dengan dominan kerusakan aksonal langsung dan demielinasi yang kemudian mengakibatkan Acute Motor
Axonopathy (AMAN) atau Acute Motor Sensory Axonopathy (AMSAN) dan kerusakan sekunder akibat mimikri molekuler antara lipopolisakarida bakteri dan GM1 manusia (Jasti et al., 2016).

Neuropati dapat disebabkan oleh agen toksik dan defisiensi vitamin. Perhatian yang cermat harus diberikan pada saat berada di tempat kerja dan rumah. Secara khusus, menghindari paparan dapat memberikan manfaat karena banyak dari paparan beracun dihasilkan dari kebiasaan baru seharihari. Sebagian besar bentuk malnutrisi tidak hanya terdapat pada masyarakat kurang mampu tetapi seseorang dengan riwayat operasi lambung, malabsorpsi kronis, atau pecandu alkohol dapat mengalami kekurangan vitamin (Shible et al., 2019).

Terapi suplementasi vitamin sebagai terapi suportif dapat digunakan oleh tenaga medis apabila sudah tidak ada respon terhadap terapi farmakologi.Terapi suportif dapat digunakan sebagai upaya preventif penyakit Guillain Barre Syndrome (Francis, 2020). Kebutuhan terapi suportif selain suplementasi vitamin dapat juga diberikan. Fungsi vitamin dalam tubuh terbagi menjadi 3, yaitu membantu proses metabolisme, membantu proses pertumbuhan, pengaturan dan perbaikan jaringan. Vitamin dihasilkan oleh sumber energi ,yaitu karbohidrat dan protein menghasilkan 4 kalori/gram sedangkan lemak menghasilkan 9 kalori/gram) (Francis, 2020).

Defisiensi yang dapat terjadi apabila kekurangan vitamin yaitu berbagai manifestasi klinis. .Zink dibutuhkan untuk mengeluarkan penyimpanan vitamin A di hati.Apabila seseorang mengalami kekurangan vitamin dalam jangka waktu lama (avitaminosis) maka dapat beresiko kematian.Tetapi resiko kematian akan berkurang apabila seseorang mengalami defisiensi vitamin B 12 dan vitamin E. Apabila seseorang memiliki cadangan nutrien yang lain maka tubuhnya akan mampu melakukan 
kelumpuhan motor ascenden yang biasanya terkait dengan GBS (Shible et al., 2019).

Temuan pemeriksaan CSF yang didapatkan pada penderita Guillain Barre Syndrome yaitu cairan bersifat jernih, terdapat pleositosis, dan rasio albumin melebihi 0,05 (terjadi disosiasi albumino-sitologikal) (Sure and Culicchia, 2013).

Penyakit iniadalah jenis penyakit saraf yang berhubungan dengan konsumsi vitamin B. Vitamin B 1 merupakan komponen makanan esensial dan dapat terjadi defisiensi mikronutrien yang mendasari beberapa penyakit, terutama gangguan sistem saraf. Sumber utama vitamin B dalam makanan adalah makanan nabati. Vitamin B 1 juga penting bagi tanaman dan bermanfaat bagi kesehatan tanaman tetapi kurang mendapat perhatian dibandingkan bidang kesehatan manusia. Secara umum, vitamin B 1 sangatlah baik bagi tubuh karena berperan sebagai koenzim dalam jalur metabolisme, terutama yang terlibat dalam produksi energi dan metabolisme sentral (Fitzpatrick and Chapman, 2020).

Tiamin (vitamin B1) adalah vitamin yang larut dalam air dan memiliki peran vital dalam metabolisme sel, khususnya dalam siklus asam trikarboksilat (siklus Krebs). Rata-rata pada orang dewasa membutuhkan sekitar 330 mcg tiamin per 1.050 kalori dengan asupan tiamin harian yang direkomendasikan sebanyak 1-1,5 mg. Kapasitas penyimpanan tiamin terbatas dalam tubuh manusia dengan jumlah rata-rata yaitu 25-30 mg yang disimpan pada satu waktu. Oleh karena itu, menurunnya kadar tiamin dapat terjadi dalam 14 hari (Shible et al., 2019).

Kekurangan tiamin dipicu oleh berkurangnya asupan tiamin karena penyalahgunaan alkohol, anoreksia nervosa, diet, atau malabsorpsi. Malabsorpsi juga dapat terjadi pada pasien diare, penyakit seliaka, sariawan, atau disentri. Penyebab lain yang jarang ditemukan adalah luka bakar, kehamilan, dialisis, dan keganasan (Shible et al., 2019).

Patologi utama defisiensi vitamin B 12 adalah kombinasi degenerasi subakut dalam medula spinalis serta kehilangan traktus kortikospinalis dan kolom posterior bersamaan dengan timbulnya neuropati perifer sensorimotor aksonal. Keterlibatan sumsum tulang belakang leher menjadi awal timbulnya penyakit serta dapat terjadi gejala sensorik di kedua tangan dan kaki yang memberikanpetunjuk etiologi (Staff and Windebank, 2014).

Tanda-tanda disfungsi

LowerMotor Neuron (LMN) dan Upper Motor Neuron (UMN) kadang-kadang muncul sebagai penurunan refleks dengan tanda Babinski (+). Kekurangan vitamin B12 juga terkait dengan disfungsi kognitif. dan anemia megaloblastik yang disebabkan peran vitamin B 12 dalam sintesis DNA (Staff and Windebank, 2014).

Pengujian untuk memastikan kondisi kekurangan vitamin B 12 harus mencakup vitamin B serum 12 dan asam metilmalonik yang merupakan penanda vitamin B seluler yang lebih akurat. Peningkatan kadar gastrin dan antibodi faktor intrinsik juga dapat terjadi. Suplemen vitamin B 12 harus diberikan secara parenteral karena penyerapan oral yang buruk biasanya merupakan penyebab penyakit. Suplementasi dengan vitamin B 12 biasanya menghentikan perkembangan penyakit, tetapi tidak dapat sembuh total karena adanya kecacatan sekunder sumsum tulang belakang (Staff and Windebank, 2014).

Selain vitamin B 12, vitamin C pun memiliki peran penting. Apabila vitamin $C$ tidak dikonsumsi maka resiko kematian akan terjadi dalam beberapa bulan. Beberapa vitamin dihasilkan di usus dan ketika dietaryniasin (vitamin B-3) rendah serta terdapat triptofan (asam anamino) maka tubuh dapat mengubah triptofaninto niasin. Vitamin A ditemukan dalam produk-produk hewani tetapi persentase substansial dari pasokan tubuh vitamin A dapat berasal dari tanaman meskipun tidak ada vitamin A dalam tanaman. Di 
dalam tanaman terdapat karoten yang diubah tubuh menjadi vitamin A (Francis, 2020).

Selain vitamin A, Vitamin D juga memiliki proses metabolisme yang sudah banyak diketahui. Vitamin D3 diproduksi dalam kulit melalui radiasi UVB hingga terbentuk 7dehidrokolesterol di kulit yang diikuti dengan reaksi suhu. Vitamin D 3 dalam bentuk peroral diubah menjadi 25(OH)D di hati dan menuju hormon metabolit 1,25(OH)2D (kalsitriol) di ginjal dan organ lainnya. Vitamin $D$ banyak didapat dari kalsitriol, reseptor nukleus vitamin D, DNA bindingprotein yang berinteraksi secara langsung melalui urutan di sekitar gen target (Grant et al., 2020).

Vitamin D3 diaktifkan secara lokal di jaringan paru-paru dan memiliki efek pencegahan pada pneumonitis interstitial eksperimental. Meskipun kemungkinan bahwa efek perlindungan vitamin D terhadap Covid19 terkait dengan penekanan respon sitokin dan mengurangi keparahan dan resiko ARDS namun terdapat bukti dari metaanalisis bahwa asupan vitamin D2 / D3 oral reguler (dalam dosis hingga 2000 IU /d tanpa bolus tambahan) bersifat aman dan protektif terhadap infeksi saluran pernapasan akut, terutama pada kondisi defisiensi vitamin (Panarese and Shahini, 2020).

Penyakit autoimun dapat terjadi karena adanya aktivasi sistem kekebalan tubuh yang menyimpang. Respon imun terjadi dengan cara melawan antigen yang tidak berbahaya.Vitamin $D$ berperan dalam meningkatkan respon imun berkat perannya sebagai salah satu bentuk protein inflamasi. Jenis protein inflamasi lainnya, yaitu : beta-2 glikoprotein I (ApoH) dan isoform komplemen C3 (Murdaca et al., 2019). Hipovitaminosis D secara genetik memiliki kecenderungan untuk merusak toleransi diri dengan melakukan kompensasi terhadap regulasi sel dendritik, regulasi limfosit $\mathrm{T}$, dan sel Th1. Kekurangan vitamin $\mathrm{D}$ juga sering terjadi pada kesehatan populasi (Murdaca et al., 2019).
Hipovitaminosis dapat menjadi dasar penentuan diagnosis GBS. Diagnosis GBS berdasarkan etiologinya dapat ditegakkan dengan skrining paraneoplastik atau autoimun lengkap pada fase akut termasuk pengujian serum antibodi onkoneural dan vaskulitis (misalnya Anti-Neutrofil Cytoplasmic Antibody / ANCA). Hasil tersebut dapat mengarah pada kemungkinan polimikuloneuropati autoimun atau polimikuloneuropati yang serupa dengan GBS. Namun, onset pasca infeksi,perjalanan klinis akut dan temuan neurofisiologi yang khas dengan riwayat negatif penyakit autoimun ,neoplastik atau gangguan neurologis sebelumnya membuat diagnosis alternatif ini menjadi kurang tepat. Keterbatasan utama lainnya bergantung pada ketersediaan serologi SARS-CoV-2 dan uji validasi CSF ,misalnya dengan PCR) (Padroni et al., 2020).

\section{KESIMPULAN}

Penyakit infeksi corona virus memiliki manifestasi klinis berupa gangguan neuroimunologi yaitu penyakit Guillain Barre syndrome. Vitamin B 1 merupakan komponen makanan esensial dan defisiensi mikronutrien yang mendasari beberapa penyakit, terutama gangguan sistem saraf.Vitamin $D$ berperan dalam meningkatkan respon imun terhadap infeksi virus ataupun bakteri. Defisiensi vitamin dapat meningkatkan resiko infeksi corona virus hingga kelainan sistem saraf berupa penyakit Guillain Barre Syndrome.

\section{SARAN}

Suplementasi vitamin yang mencukupi di kala pandemi ini sangatlah dibutuhkan untuk meningkatkan imunitas dan mengurangi resiko terjadinya penyakit yang menyerang sistem saraf.

\section{DAFTAR PUSTAKA}

Asadi-pooya, A. A. (2020) 'Since January 2020 Elsevier has created a COVID-19 resource centre with free information in 
English and Mandarin on the novel coronavirus COVID- 19 . The COVID-19 resource centre is hosted on Elsevier Connect, the company's public news and information.

Bild, G. K. and Aheta, M. (2015)

Guillain-Barré syndrome : clinical profile and management.GMS German Medical Science13.

Fitzpatrick, T. B. and Chapman, L. M. (2020) The importance of thiamine (vitamin B1) in plant health: From crop yield to biofortification. The Journal of biological chemistry. doi: 10.1074/jbc. REV120.010918.

Francis, M. (2020). Using Nutrition Against Aging and Degenerative Disease. ERIC.

Grant, W. B. et al. (2020). Evidence that vitamin $\mathrm{D}$ supplementation could reduce risk of influenza and covid-19 infections and deaths. Nutrients12(4): 1-19. doi: $10.3390 /$ nu12040988.

Hastie, C. E. et al. (2020) .Vitamin D concentrations and COVID-19 infection in UK Biobank. Diabetes \& Metabolic Syndrome: Clinical Research \& Reviews.

Jasti, A. K. et al. (2016). PROOF COVER SHEET Journal acronym: IERM Author(s). Division of Rheumatology, Allergy and Clinical Immunology, University of California at Davis School of Medicine. Available at: http://journalauthors.tandf.co.u k/preparation/writing.asp.

Kannan, S. et al. (2020). COVID-19 (Novel Coronavirus 2019) recent trends. European Review for Medical and Pharmacological Sciences24(4):2006-2011. doi: 10.26355/eurrev_202002_2037

8.

Murdaca, G. et al. (2019). Emerging role of vitamin $D$ in autoimmune diseases: an update on evidence and implications.Autoimmunity Reviews.

Needham, E. J. et al. (2020). Neurological Implications of
COVID-19

Infections.

Neurocritical Care. Springer US 32(3): 667-671. doi: 10.1007/s12028-020-00978-4.

Padroni, M. et al. (2020). Guillain-Barré syndrome following COVID-19: new infection, old complication?. Journal of Neurology. Springer Berlin Heidelberg (Table 1): 1-3. doi: $\quad 10.1007 / s 00415-020-$ 09849-6.

Panarese, A. and Shahini, E. (2020). Letter: Covid-19, and vitamin D.Alimentary Pharmacology and Therapeutics 51(10):993-995. doi: 10.1111/apt.15752.

Shible, A. A. et al. (2019). Dry beriberi due to thiamine deficiency associated with peripheral neuropathy and wernicke's encephalopathy mimicking guillainbarré syndrome: A case report and review of the literature. American Journal of Case Reports 20 : 330-334. doi: 10.12659/AJCR.914051.

Staff, N. P. and Windebank, A. J. (2014). Peripheral neuropathy due to vitamin deficiency, toxins, and medications. CONTINUUM Lifelong Learning in Neurology 20(5): 1293-1306. doi:

10.1212/01.CON.0000455880.0 6675.5a.

Sure, D. R. and Culicchia, F. (2013).Duus' Topical Diagnosis in Neurology, Otology \& Neurotology. doi: $10.1097 / \mathrm{mao} .0 \mathrm{~b} 013 \mathrm{e} 318271$ c396. 